\title{
Musca Domestica: A Vector of Pathogenic Microorganisms and Biocontrol Approaches
}

\author{
By Abir S. Al-Nasser, Dina E. El-Ghwas \& Aisha A. Al-Sheikhy
}

University of Jeddah

Abstract- House fly "Musca domestica" Linnaeus is a common insect widely distributed all over the world and is one of the domestic insect pests found associated with human and animal. Due to their habits and habitats, house flies are able to transmit several pathogenic microorganisms to man such as: bacteria, fungi and virus. House flies are not just annoying human and animal, but they also have been known as vectors of infectious microorganisms either mechanically or biologically. Chemical insecticides have been used for many years and have been known as the most effective approach in house fly management but due to their side effects on the environment and the increasing development of pest resistance to each new chemical, studies tended to explore new alternative methods in pest control. Biological methods including different predators, parasites, entomopathogenic micro-organisms and botanical extracts showed in the last years a practical and effective ecofriendly method to control insect pests including house fly and at the same time safe on human and animal.

Keywords: house fly, musca domestica, pathogens, microorganisms biocontrol.

GJSFR-C Classification: FOR Code: 279999

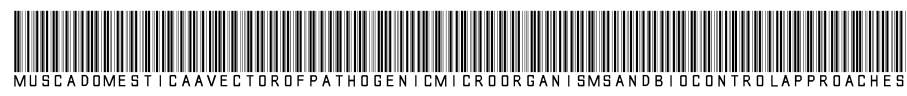

Strictly as per the compliance and regulations of:

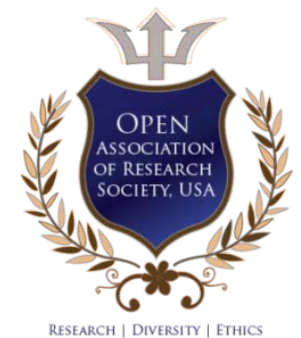

(C) 2021. Abir S. Al-Nasser, Dina E. El-Ghwas \& Aisha A. Al-Sheikhy. This is a research/review paper, distributed under the terms of the Creative Commons Attribution-Noncommercial 3.0 Unported License http://creativecommons.org/licenses/by-nc/3.0/), permitting all non commercial use, distribution, and reproduction in any medium, provided the original work is properly cited. 


\title{
Musca Domestica: A Vector of Pathogenic Microorganisms and Biocontrol Approaches
}

\author{
Abir S. Al-Nasser ${ }^{\alpha}$, Dina E. El-Ghwas ${ }^{\sigma}$ \& Aisha A. Al-Sheikhy ${ }^{\rho}$
}

\begin{abstract}
House fly "Musca domestica" Linnaeus is a common insect widely distributed all over the world and is one of the domestic insect pests found associated with human and animal. Due to their habits and habitats, house flies are able to transmit several pathogenic microorganisms to man such as: bacteria, fungi and virus. House flies are not just annoying human and animal, but they also have been known as vectors of infectious microorganisms either mechanically or biologically. Chemical insecticides have been used for many years and have been known as the most effective approach in house fly management but due to their side effects on the environment and the increasing development of pest resistance to each new chemical, studies tended to explore new alternative methods in pest control. Biological methods including different predators, parasites, entomopathogenic micro-organisms and botanical extracts showed in the last years a practical and effective ecofriendly method to control insect pests including house fly and at the same time safe on human and animal.
\end{abstract}

Keywords: house fly, musca domestica, pathogens, microorganisms biocontrol.

\section{INTRODUCTION}

B ecause house fly lives close with human, it finalizes its entire life cycle in human houses and their domestic animals. Musca domestica Linnaeus can be found in human residences, hospitals, food processing factories, food markets, butchery, food centers or restaurants, poultry and livestock farms, and different domestic areas or buildings. House flies can be a cause of decreasing the production of milk in dairies. Therefore, recently significant emphasis has been given to fly control measures (Crespo et al., 1998).

Repeated interaction of the fly with different animals and wastes provides an occasion forthe mechanical transmission of diseases to both human and animal (Davari et al., 2010; Fisher et al., 2017). Places with vast quantities of dung or manure, such as animal raising houses and sites without human cleanliness practices, represent favorable conditions for the dissemination of house flies and simultaneous procurement of bacteria (Meerburg et al., 2007). Though, the concentration, possibility, and species dissemination of bacteria in animal excrement or compost differ broadly among places and within hosts

Author a $\rho$ : Department of Biology, Faculty of Science, University of Jeddah, Jeddah, Saudi Arabia.

Author $\sigma$ : Chemistry of Natural and Microbial products Department, National Research Centre, Dokki, Egypt.

e-mails: aalnasser@uj.edu.sa, al-nasser.abir@hotmail.com
(Himathongkham et al., 1999). Therefore, flies might confront and eat highly varying quantities of bacteria throughout their connotations with animal trashes (Ahmad et al., 2011). The feeding habits of house fly are one of the most harmful characteristics because it is exposed to decaying plant and animal matter, this put fly in contact with pathogenic organisms found in various environments, garbage, and animal waste (Park et al., 2019).

Flies carrying pathogens are usually found with human and animal wastes and waste management then propagates to human dwelling and activity (Sulaiman et al., 2000; Mian et al., 2002). House fly, Musca domestica, and stable fly, Stomoxys calcitrans can transmit injurious pathogens to humans and animals in urban and rural regions. These species can cause irritation to farmers and affect animal health causing a decline in the production of cattle and rooster. They breed in organic matter causing problems in places where organic waste is stored such as waste management facilities (Malik et al., 2007; Taylor et al., 2012 and Weeks et al., 2017). As a result of its life and conduct, flies have been involved as a vector of pathogenic microbes by mechanical and biological route (Graczyk et al., 2001; Zurek and Ghosh, 2014).

Park et al.(2019), investigated the inner and outer microbial fauna in 400 samples of house flies from three different environments (cow farm, homes, and clinics) in Belgium and Rwanda. They reported that whatever was the nation or territory, house flies ported a high potential of various bacterial microbiota and that bacterial communities on the external body were much more various than the internal populations from the intestinal gut. Various researches reported the effect of house fly in transmitting different pathogens including bacterial, viral, rickettsial, and helminthic diseases(Sanchez-Arroyo and Capinera, 2014; Shah et al., 2015), which causes infections such as enteric infections (dysentery, diarrhea, typhoid, cholera, and certain helminth infections), eye infections (trachoma and epidemic conjunctivitis, poliomyelitis), skin infections (yaws, cutaneous diphtheria, some mycoses, and leprosy) (Bahrndorffet al., 2017; Baharethet al., 2018).

Hulten et al.(1996), indicated that there are three different possible modes of bacterial transmission by flies. A confirming study by Thomas et al. (1992) and Kelly et al. (1994), reported the isolation of viable . 
bacteria from feces. Thus, suggesting that transmission through the fecal-oral route seems possible. In Malaysia, Tan et al.(1997), performed their study on how house fly could transmit rotavirus on their different body parts.

When flies feed on bacteria, they can keep these bacteria in their guts for several days, then propagate them in the ecosystem. Kobayashi et al. (1999), observed many bacteria in the foregut of the flies (crop) until four days after feeding it on E. coli O157: $\mathrm{H} 7$. Zurek et al. (2001), mentioned that the bacteria persisted in the house fly digestive system for 36 hours after feeding it on Yersinia tuberculosis. Aeromonas caviae was replicated in house flies for about 2 days and endured for up to 8 days post digestion, and a large number of viable bacteria were shed in vomitus and feces (Nayduch et al., 2002). Similarly, Pseudomonas aeruginosa proliferated and persisted in house flies, and has been discarded in excreta for at least 24 hours post-ingestion (Joyner et al., 2013).

Control procedures are normally established on the use of chemicals, insect pesticides have been widely utilized for house fly control (van Emden and Peakall, 1996). These chemical pesticides hold prospective dangers for both the environment as well as human health and continuously lead to the development of resistance to most used insecticides (Asaeedi et al., 2017).Various pesticides used to control flies showed harmful effects on non-objective organisms, involving those that are natural control agents, such as predators and parasitoids (Scott et al., 1991). To diminish harmful effects on health, environment and to prevent pollution of the ecosystem, research for new highly efficient alternative strategies for pest control such as biopesticides has increased (Rodrigues et al., 1988; Zimmer et al., 2013). Besides, insecticides and insect growth regulators, attention has been given to biological control of flies especially in livestock units where predators and parasites may be used to control fly populations (Noorman, 2001). Among bioinsecticides, efforts focused on pathogenic organisms such as nematodes, fungi, bacteria, and viruses (Geden, 2012; Ruiu et al., 2013). The application of different procedures in house fly control is necessary to limit and suppress this pest and to prevent the transmission of infectious diseases to humans and animals. For that, health education, appropriate environmental cleanliness, and personal sanitation are reassured (Issa, 2019). Because of their high dispersion in the ecosystem, bacteria could develop different interactions with insects such as symbiosis (Feldhaar, 2011).

While several bacterial species occupy insect bodies and create various degrees of reciprocal relationships, only a small number of them act as insect diseases, developing several strategies to enter the host, conquer, influence, and destroy its immune responses (Vilcinskas, 2010).

\section{Biology of House Fly}

House fly $M$. domestica has a full metamorphosis including clear egg, larval, pupal, and adult stages (Cossé and Baker 1996). House flies can live from 15-30 days, females become sexually mature within 2-3 days post-emergence and mate once, while males usually mate several times from the day of their emergence (Saccà, 1964). Oviposition takes place four days after copulation and the female lays several batches of 100 to 155 eggs for 3-4 days, during its lifetime. Females deposit eggs in a humid medium such as cracks and crevices to protect them from dryness, their main breeding areas are usually manure and spilled food (Kelling, 2001; Weeks et al., 2017). Usually, warm summer conditions are ideal for their development as they can complete their life cycle within 7-10 days. While under undesirable conditions life cycle may need two months. In temperate regions, around 10 generations may occur annually, while more than 20 generations may occur in subtropical and tropical regions (Weeks et al., 2017).

Whitish $1 \mathrm{~mm}$ long eggs hatch after 8-20 hours post oviposition. Saprophytic larvae, white and legless grow through three instars for 4-13 days (Sarwar, 2016). Each of the first and second larval stages lasts around 1-3 days, the third in star larva develops in 3-4 days to a creamy white 8-11 $\mathrm{mm}$ long maggot, tapering from the front and thicker behind to a shortened back end, where two apparent black spiracles are placed through which the tracheal system is attached with the exterior air (Kelling, 2001). At optimum temperature $\left(32-37^{\circ} \mathrm{C}\right)$, pupae could finalize their growth for 2-6 days. Thus, the entire life cycle from egg to adult laying eggs ranges from 14-18 days under ideal conditions $\left(25^{\circ} \mathrm{C}\right)$. Numerous generations could grow up during the warm season, but in unfavorable conditions, it could be slow down to nearly six weeks giving emergence to abnormally low size offlies (Kelling, 2001).

\section{ili. Pathogens Transmitted by House Fly}

The most known way for house fly to transmit pathogens is mechanically (Fisher et al., 2017). Hence, some reports have shown that house fly is a disruptive pest and an important pathogenic micro-organism vector such as bacteria, viruses, fungi, and protozoa among human and animal (Sanchez-Arroyo and Capinera, 2014). Adults houseflies consume human foodstuff, various excretions, animal compost, moisture, meat potage, milk, trash, and damp or decomposing material of pet litter because of their strong odor. They usually suck up their food through their proboscis because they cannot grind or chew.

If a fly sucks up food from any infectious source, some of the germs attach to the fly's mouth/body part, and when the fly comes in contact with human food, pathogens move on it (Malik et al., 
2007). Szalanski et al. (2004) reported that flies breeding in feces and other organic waste could become inhabited with pathogenic bacteria such as Escherichia coli O157:H7, which affects humans with hemorrhagic colitis and Campylobacter. Moreover, Rosef and Kapperud (1983) separated 161 strains of Campylobacter fetus subsp. Jejuni from house flies. They noticed that their carrier rates were $50.7 \%$ and $43.2 \%$ in farms of chicken and pig, respectively. They assumed that flies play a connecting function in the epidemiology of Campylobacter contamination in humans by spreading these bacteria from animals to human nutrition. Sukontason et al. (2000), in North Thailand and urban areas of Chiang Mai province, evaluated the number of bacteria on house flies and found that about 60 percent of the $M$. domestica flies transported around 1 to 5 strains of bacteria and that Staphylococci were the most excessive. Various studies isolated highly infectious bacteria from house flies, comprising enteropathogenic strains such as enterotoxigenic E. coli (ETEC), enteroaggregative E. coli (EAEC), enterohaemorrhagic E. coli (EHEC), and enteropathogenic E. coli (EPEC) (Fleming et al., 2014; Solà-Ginés et al., 2015; Songe et al., 2017).

The areas of flies' collection are related to the micro-organisms transmitted by these insects. Places such as hospitals and animal farms where antibiotic and growth stimulators are applied extensively had flies carrying antimicrobial-resistant micro-organisms (Davariet al., 2010; Nazari et al., 2017). Previously, Rady et al. (1992) isolated 21 bacterial species of house flies collected from four general hospitals in Cairo (Egypt). Nine species of Enterobacteriaceae, two species of Brucellaceae, one species of Acromobacteriaceae, and Pseudomonodaceae. Boulesteix et al. (2005) also explored how the house fly is spreading multi-resistant microbes at the intensive care units of hospitals in subSaharan Africa. They revealed that 99 flies from 120 carried human pathogenic micro-organisms, and alarmingly, 17 flies carried antibiotic-resistant bacterial strains (including methicillin-resistant Staphylococcus and ticarcillin resistant Pseudomonas). Furthermore, Khamesipour et al. (2018), were able to isolate 130 pathogenic organisms from the house fly were bacteria was the most frequent.

In their study, Macovei and Zurek (2006) mentioned that houseflies in food-handling and supply amenities houseflies can transport and may be able to deliver antibiotic-resistant and potentially virulent bacteria. Moreover, several studies registered multiple antibiotic bacterial species isolated from house flies: $E$. coli; Klebsiella pneumoniae (Davari et al., 2010; Fotedar et al., 1992) and Pseudomonas aeruginosa (Davari et al., 2010; Hemmatinezhad et al., 2015). On the other hand, Olsen and Hammack (2000) isolated Salmonella enteritidis, S. infantis, and S. Heidelberg from house flies around poultry houses. Also, Nazni et al. (2005) isolated
Bacillus sp., Staphylococcus sp. and Micrococcus sp. from feces and spews of houseflies extra than from their outer body. In India, during a craze, Fotedar (2001) showed the ability of house flies as a vector in transmitting Vibrio cholerae.

Reports indicated that antimicrobial-resistant strains responsible for $10 \%$ of in-hospital nosocomial infections such as Klebsiella species were transmitted by pests, including house flies and cockroaches (Fotedar et al., 1991; Davari et al., 2010; Tajbakhsh et al., 2015).In Japan, Sasaki et al. (2000) mentioned that house flies transmitted a toxic strain of Escherichia coli. Moreover, the World Health Organization (2004) reported that just trachoma transmitted by fly can cause six million cases of childhood blindness yearly. Because of their high activity, house flies are involved in transmitting many severe and widespread diseases. Flies come into contact with excreta, cadavers, garbage, and different infected matter, and at the same time, flies are closely associated with human's food and tools (Keiding 1986; Nichols, 2005). The kind and quantity of micro-organisms transported by flies are closely related to the presence of these organisms in the excreta and other wastes where flies grow and feed (Nichols, 2005). Usually, most antibiotic species have been secluded from insects collected from hospital and farms (SolàGinéset al., 2015; Hemmatinezhad et al., 2015; Nazari et al., 2017), signifying that house fly shows a part in propagation of antibiotic-resistant species in the ecosystem (Zurek and Ghosh, 2014). A growing problem in hospitals and other health care facilities is house flies' involvement in transmitting life-frightening antibiotic-resistant bacteria (Boulesteix et al. 2005; Macovei and Zurek, 2006). A recent study, mentioned the contribution of house flyin the spread of avian influenza (Graham et al., 2009).

Because $M$. domestica can bear a variety of bacteria, viruses, fungi, and parasites diseases over their appendages, several significant steps should be accomplished to combat these micro-organisms. One of these actions is to recognize pathogenic agents that enhance health civilization's status and monitor and reduce the population of house flies in human and animal activities (Service, 2000).

IV. Different Approaches used for House Fly Control

\section{a) Mechanical control}

Some self-protection behaviors prevent house flies by frequent cleanliness of indoor and the correct way of removing recycling rubbish (Urban and Broce, 2000). It is of importance to enhance ecological purification and hygiene to control house flies (Keiding, 1986). Effective control method for house flies producing in domestic and animal wastes is by removing properly compost or any other organic matter causing 
propagation of house fly eggs. Around 50\% of houseflies in metropolitan areas occur due to poor management in arranging waste materials from houses, hospitals, and markets.

\section{b) Physical control}

Numerous pests are susceptible to ultraviolet light with a frequency of roughly $350 \mathrm{~nm}$. The adults of houseflies are phototactic positively and are captivated to light blue-green (450-550 nm) and ultraviolet (340-365 nm) (Bellingham and Anderson, 1993). Thus, electrocuting traps with fluorescent lamps emitting light in the ultraviolet range are usually used for indoor control of houseflies (Bellingham and Anderson, 1993; Sanchez-Arroyo and Capinera, 2014). It is challenging to preserve a hygienic ambiance and avoid house flies from transmitting diseases. As a substitute, through different physical methods such as light traps, adhesive tapes, fly swats, and electrocuting grids, monitoring the house fly population can be achieved. These techniques are used to precisely kill, repel, or capture the flies without creating any resistance in the flies' body, as observed in the case of chemical insecticides. Methods for physical control are simple and very secure to use. They often do not influence the surroundings but are not very effective in controlling a high density of house flies (Urban and Broce, 2000).

\section{c) Chemical control}

Numerous chemical compounds affect different insect systems, including the nervous system, energy production, cuticle production; endocrine system, or water stability that can also be used through various application modes such as topical application, baits, and fumigants to effectively manage house fly population (Shen and Plapp, 1990; Oi et al., 1992).For many years, house fly control has been performed by treating the surfaces where the flies usually rest with different chemical compounds such as chlorinated hydrocarbons Dichlorodiphenyltrichloroethane known as DDT and methoxychlor, as well as other (lindane, and chlordane), organophosphates (malathion, diazinon, and dimethoate), carbamates (methomyl), pyrethrins (usually with piperonyl butoxide), pyrethroids (permethrin, fenvalerate, and cyfluthrin), and most recently spinosad (limited use) and neonicotinoid baits (imidacloprid) (Noorman, 2001).

Although chemical insecticides were toxic against a large selection of pests, they also affected non-target organisms. These substances cannot be decayed by organisms and their residues sustained in the environment, get into the food chains, and stored in the body tissue of non-target organisms, as well as humans (Pimental \& Perkins, 1980).In addition to the increase of tolerance and resistance of flies to insecticides, the high costs of using insecticides and their toxicity to other organisms make them less desirable for fly control.
Over the years, new pesticides were produced but flies reacted by producing resistance to organophosphate, carbamate, and pyrethroid pesticides (Kozaki et al., 2009; Memmi, 2010). The continual introduction of flies to chemicals has encouraged the development of pesticide resistance (Sanchez-Arroyo and Capinera, 2014). Further pesticides that are safe for mammals were synthetic pyrethroids, although they could affect crustaceans and fish. But, at the same time some of these products are biologically broken down (Hill, 1985).

\section{d) Botanical control}

Basic oils insecticides, have been well-known for their fumigant properties, and their method of activity might include components that inhibit the acetylchol inesterase and octopaminergic impacts (Isman, 2000). More impacts could be found in the behavior variation (attraction/repellency) and contact harmfulness for several life stages (Koul et al., 2008). Normal oils are composed of numerous biological active constituents, including terpenes, acyclic monoterpene alcohols, monocyclic alcohols, aliphatic aldehydes, sweetsmelling phenols, monocyclic ketones, bicyclic monoterpene ketones, acids, and esters (Koul et al., 2008). For this purpose, a massive effort was performed to investigate different components similar to the established essential oils effective as insecticides (Isman, 2000; Koul et al., 2008).

Terpenoids showed different effects on house flies. Some compounds had an attractant effect, others acted as a repellent of females, and both inhibited the larval development (Sharma and Saxena, 1974). Furthermore, Neem extracts and Azadirachtin had been somewhat effective against larvae of the horn fly (Haematobiairritans), however, doses required to kill house fly larvae were not useful because they were too high to be manipulated (Miller and Chamberlain, 1989).

The effect of essential oils as insecticide and repellent in flies' control has been reported in several research such as essential oils from orange peel and eucalyptus (Palacios et al., 2009 a, b); essential oils of pennyroyal mint (Mentha pulegium) and rosemary (Rosemarinus officinalis) Pavela (2008). Ezeonu et al. (2001), also reported that sweet orange peel extracts (Citrus sinensis) showed a positive effect on adult house flies when used as fumigants. Moreover, Kumar et al. (2011), reported that between 6 plant extracts that have been investigated against house fly (Mentha piperita) and blue gum (Eucalyptus globulus) were the most efficient as insecticidal and repellents. Also, Urzuaet al. (2010), reported that essential oils from Haplopappus foliosus (Asteraceae) were effective on adult house flies. Hence, plant extracts can be used as larvicidal, pupicidal, and adulticidal. Others act as repellents, feeding inhibitors, oviposition reducing, and insect growth managers for house fly as well as for some other 
pests (Tsao et al., 1995). Botanical pesticides could be economically and ecologically beneficial as these are more specific than chemical pesticides and do not affect the non-target organism (Willikins and Metcalfe, 1993). Plant oils effect of on flies varies with the sex and the developmental stage of the house fly and the mode of application (Malik et al., 2007).

\section{e) Hormonal control}

Searches for alternatives other than insecticides have increased in the last years. Insect growth regulators are called third-generation pesticides. They do not usually kill the target pest immediately, these substances show some selectivity and take a longer time to reduce insect populations than with nerve insecticides (Myamoto et al., 1993). Lindquist et al. (1992), mentioned that discharging sterilized male flies could destroy flies population as it was effective against the screwworm fly Cochliomyia homonivorain Libya. Also, Howard and Wall (1996 b, c), used triflumuron in sugar -baited targets to sterilize house flies, and they reported that this chemical could decrease the population of house flies in combination with the discharge of predators and parasites. Anyhow, usage of sterile insect technique (SIT) has been constrained by its high cost and logistic complication. Otherwise, discharging a large number of sterilized males around human residency could increase the frustration problem at least for a brief time. Anyhow insect growth regulators IGRs, have no dangerous influences on humans, animals or the environment when applied as listed on the product labels (Oberlander et al. 1997). Though widespread resistance against IGRs, also has developed (Pap and Farkas, 1994).

\section{f) Biological control}

There are various substitutes to chemical insecticides for house fly control (Achiano and Giliomee, 2005). Entomopathogenic bacteria are additional alternatives to chemical compounds. In addition to their effectiveness, such as safety for humans and other nontarget species, elimination of pesticides left in food, defense of natural enemies, and improved biodiversity in the environment, various benefits can be seen in using entomopathogens. Although there are several natural enemies of house flies such as entomopathogenic bacteria, fungi, nematodes, predatory beetles, parasitic wasps, mites, flies, and birds, few cases showed successful results of control by natural enemies, mainly when mixed with other control strategies (integrated fly control) (Urzua et al., 2010).Because pathogenic fungi could be found on animal supplies, their activity varies on temperature and moisture. Besides, contamination of flies in summer is not very high, while it is most needed in summer (Hung and Gerry, 2013). Hence, natural enemies are thought to successfully suppressing the fly, if the right genus and strains are employed in the right region (Pawson \& Petersen, 1988).

\section{Parasites and Predators}

King (1997), explored the efficacy of the parasitoid wasps Spalangia cameroni and Muscidifurax raptor in controlling fly populations and reported that $S$. cameroni alone seemed to be reliably more efficient in destroying flies' pupae than $M$. raptor. Greene et al. (1998), reported that the parasitoid Spalangianigroaenea induced mortality in pupae of $M$. domestica by 23 to 58 $\%$, depending on the parasitoid to host ratio. Moreover, Spalangia cameroni Perkins and Muscidifurax raptor Girault and Sanders (Hymenoptera: Pteromalidae) are ectoparasites of filth fly and they are widely distributed (Taylor et al., 2006). These two pupal parasitoid species are commercially available to control house flyMusca domestica L. and stable flies Stomoxys calcitrans (L.), two pests of medical and veterinary importance. Some researchers pronounced that parasitoids wasps (Pteromalid) that attack pupae were used for fly management as they are the best biocontrol agents (Skovgaard and Nachman, 2004; Geden and Hogsette, 2006), Tsankova and Luvchiev (1993), mentioned that the second and third instar larvae of Ophyra capensis can execute as much as 17 housefly larvae varying on the larval instar and the population density. Some studies reported the effect of Histerid beetles and macrochelidae mites as predators on egg and larvae of house flies (Kaufman et al., 2002; Achiano and Giliomee, 2005).

\section{Entomopathogenic Nematodes}

Entomopathogenic Nematodes are small roundworms (much less than 1-3mm), parasites of soilinhabiting insects. These parasites are stated as insecticidal nematodes, such as some species within the genus Steinernema(family: Steinernematidae) and Heterorhabditis (family: Heterorhabditidae) of the Phylum Nematoda (Mwamburi,2008). Steinernematid and heterrhabditid nematodes when used in the control of filth flies, the larval stage was very sensitive to these entomopathogenic nematodes (Mullens et al., 1987; Taylor et al., 1998). There is a mutualistic association between Nematodes and micro-organism inhabiting their digestive tracts, these bacteria execute the insect after the nematode conquers its body, some of these bacteria species are Xenorhabdis nematophilisis associated with Steinernematid Steinernema carpocapsae while Photorhabdis luminescensis associated with Heterorhabditis bacteriophora (Kaya and Gaugler, 1993; Mwamburi, 2008).Penetration of nematodes into the insect body depends on the host and nematode species, although there are many methods of penetrations such as the mouth or the anus the infection of house fly larvae and leaf miners is through the anus mainly (Renn, 1998), some studies mentioned that the mouth is the most successful way (Cui et al., 1993). Steinernema feltiae can go into the 
body insect via the cuticle or the inter segmental membranes, penetration through the integument was shown to be their main route of entry (Peters and Ehlers, 1994). An Additional way of entry to the adult insect is the genital openings (Samish and Glazer, 1992). After entering the hemocoel, nematodes feed on the blood, and at the same time, they evacuate the excretions, discharging the symbiotic bacteria (Martens et al., 2004). Bacteria rapidly inhabits the insect and kill it for 1 to 3 days. The nematodes consume the bacteria and tissues of the larval body, it develops and undergo 2-3 generations in a period ranging from one to 2 weeks. The last generation leaves the cadaver searching for a new host (Ciche et al., 2006). Bacteria from nematode destroy the insect as soon as it enters its body, so it cannot form a host-parasite relation. This allows the nematode to visit many hosts and cover most insects' orders (Grewal and Georgis, 1999). The tough behavioral barrier in some insect hosts could limit the efficacy of nematode (Gaugler, 1988).

\section{Vil. Entomopathogenic Fungi}

Some studies have evaluated the effect of infective fungi for house fly management in the field such as Entomophthora muscae (Cohn) Fresenius, and they mentioned that sometimes the pathogenic $E$. muscae could destroy fly populations (Geden et al., 1993; Steinkraus et al., 1993; Watson and Petersen, 1993).Kuramoto and Shimazu (1997), used house flies infected with Entomophthora muscae in experimental poultry houses, these flies were able to kill $90 \%$ of the originally existing flies after 33 days of their introduction. Normally, the effect of Beauveria bassiana and Metarhizium anisopliae against house flies and stable flies are low in the field (Skovgaard and Steenberg, 2002). Nevertheless, they showed a high effect in the laboratory trials against larval and adult flies, their virulency depends on the strain and the formulations (Lecuona et al., 2005). It is important to use a mixture of pathogenic fungi with chemical insecticides to improve their effectiveness as biological control (Ericsson et al., 2007). Fungi enter the body of the insect through the cuticle (Charnley, 1989) or the trachea (Feng et al., 1994). The conidia attach to the cuticle (Boucias and Pendland, 1991), then germination begins and the insect becomes infected. The hyphae penetrate the cuticle and proliferate into the hemocoel, which causes the insect's death due to toxemia (Khachatourians, 1991).

\section{Vili. Entomopathogenic Virus}

One of the Hytrosaviridae family is the salivary gland hypertrophy virus that contaminates house flies, tsetse flies (Glossina spp.), and the narcissus bulb fly (Merodon equestris Fabr.) (Lietze et al., 2011). Contaminated flies do not show any external disease signs. The most visible infection characteristic is the incidence of significantly enlarged (hypertrophied) salivary glands with a blue-whitish presence that often dominates the abdominal cavity of the fly after dissection. Viral duplication and morphogenesis are confined to salivary gland cells, although complete virions are also found in asymptomatic tissues such as the midgut, ovaries, fat body, and brain (Lietze et al., 2010). The virus in both sexes of infected flies causes a decrease in mating achievement and shorten life periods. Sustainable virus particles pass by the digestive system of infested flies and are evacuated with feces, even if at low rates (Lietze et al., 2007; Lietze et al., 2009).

\section{iX. Entomopathogenic Bacteria}

To reduce the effect of chemicals on health and the ecosystem, other selected approaches have been applied for insect control. Many different genera of micro-organisms have been utilized as biological insecticides (Rodrigues et al., 1988), and there is a tremendous review on the insecticidal impacts of Bacillus thuringiensis(Bt) beside the different isolates that are effective against house fly(Ruiu et al., 2006). B. thuringiensis, has many advantages over conventional pesticides, itis specific to certain pest species, ecofriendly, and safe to non-target organisms, mosquitoes did not develop significant resistance to it in the field so far (Bravo et al., 2007).Johnson et al. (1998), described the utilization of Bacillus thuringiensis as a protected and successful method for controlling rural pest and particularly houseflies. The active factor in the bacteria is a member of Cry IB class of protoxins, and it is created in some strains of $B$. thuringiensis.

Carramaschi et al. (2015), reported that Brevibacillus laterosporus (Laubach) is a biological control agent. It showed broad entomopathogenic activity against various insects such as blowflies (Pessanha et al., 2015) and house flies (Ruiu et al., 2006; Ruiu et al., 2008; Ruiu et al., 2011; Zimmer et al., 2013). Innovative bacterial species with advanced methods of action have been found and prepared as new biological insecticide products (Ruiu et al., 2013). Bacillus thuringiensis has proven an enormous potential factor in the control of livestock pests. Investigation and improvement of the toxins and their method of activity against pests are progressing in several countries (Pinnock, 1994). The impact of Bacillus thuringiensis against filth flies was encouraging, the control against larvae was achieved by feeding cattle and chickens with a spore formulation of $B t$ bacteria in that way animals can deliver these bacteria in the manure known as house flies rearing places (Miller et al., 1971), also by blending Bt straight forwardly with fly reproducing substrates (Rupes et al., 1987). Some studies used the exotoxin delivering $B t$ strains where flies showed higher 
sensitivity than most other pests to the exotoxin (Carlberg, 1986). Indrasith et al. (1992), and Johnson et al. (1998), detected numerous strains to be effective against adult house flies, and they mentioned that all the Musca domestica-active strains had in them the endotoxin Cry1B which might be the key entry of these strains effect against house flies (Lysyk et al., 2010). Bacillus thuringiensis was found to be more efficient against house fly when mixed with poultry food rather than added directly to the manure (Labib and Rady, 2001). Additional to the crystal-related poisonous proteins related to sporulation, some $B t$ isolates can produce proteins during their development such as vegetative insecticidal proteins. These vegetative proteins were effective against a big range of Lepidoptera (Estruch et al., 1996; Schnepf et al., 1998).

Most researches have focused on the validity of Bton pest insects that are routes of human infections (Kellar and Langenfruch, 1993; Rajakulendran, 1993; Teakle, 1994). B. thuringiensis israelensis were applied as a pesticide compound to control medical dipteran pests such as mosquitoes and blackflies (MullaBecker and Margalit, 1993; Becker, 1997), Btisraelensis showed toxicity to the house fly (Zhong et al., 2000).

The oral effect of bacterial toxins crystalogenic proteins (Cry) and cytolytic (Cyt) affect the larval stage by stimulating the formation of cell membrane lytic pore in the lining epithelia of the midgut, which causes an increase in the permeability of the membrane, paralysis of the intestine, stop digestion and finally kills the larva (Kongsuwan et al., 2005). The recognition of insecticidal bacterial strains against the synanthropic housefly is of great importance. Zimmer et al.(2013), evaluated (in artificial medium) the entomopathogenic effects of $B$. laterosporus (BI), $B$. thuringiensis var. israelensis (Bti), $B$. thuringiensis var. kurstaki (Btk), against immature and adult life stages of $M$. domestica. There is a convincing opportunity for using microbial control agents against flies as they are reasonably selective, active, and there are many options for implementations. Bacillus thuringiensis (Berliner) (Bt) is a naturally occurring bacterium creating proteins that are active as insecticides against many species.

\section{House fly and antimicrobial resistance strains}

Regrettably, restricting the human diseases transferred by house flies has not been successful due to the shortage of knowledge of this species' basic molecular process (Scott et al., 2009). Adjustment to distinct ecological environments might result in the progression of specific immunity of house flies. Therefore, comparing the instinctive immune systems of Musca domestica with those of the species that face different ecological pressures and pathogens such as Drosophila and Anopheles can be very informative and thus offer clues on how house flies can flourish in close contact with many pathogens (Scott et al., 2009).
There are some public health concerns regarding the global use of agricultural antibiotic and the increasing of drug-resistant bacteria(Levy \& Marshall 2004; Erb et al., 2007). A significant quantity of antibiotic-resistant bacteria with resistant genes have been found in poultry litter, where antibiotics are used to produce poultry (Nandi et al., 2004). The house fly could take part in in disseminating these antibiotic-resistant bacteria from the poultry or hospital areas to the ecosystem (Winpisinger et al., 2005; Akter et al., 2020). The antibiotic-resistant enterococci and staphylococci have been isolated from poultry litter (Hayes et al., 2004; Simjee et al., 2007).

\section{Conclusion}

Several studies confirmed the competence of house flies in dispersing numerous species of microorganisms. Hence, the flies transport these microorganisms, including bacterial species on their body surface or through their internal digestive tract and transmit them to human and animal food while their feeding mechanism. Previous studies indicated that among the bacteria transmitted by house fly, some antibiotic-resistant species worsen the problem. Recently, different species of bacteria proved their efficiency in reducing the population density of house fly. Therefore, it is of importance that researchers focus on biological pest control to avoid the damage inflicted by chemical insecticides.

\section{Abbreviations}

\section{Bt: Bacillus thuringiensis}

\section{E. coli: Escherichia coli}

M. domestica L.: Musca domestica Linnaeus

\section{References Références Referencias}

1. Achiano KA, Giliomee JH. 2005. Biology of the house fly predator Carcinopspumilio (Erichson) (Coleoptera: Histeridae). Biocontrol 50: 899-910.

2. Ahmad A, Ghosh A, Schal C, Zurek L. 2011. Insects in confined swine operations carry a large antibiotic resistant and potentially virulent enterococcal community. BMC Microbiology 11:23.

3. Akter S, Sabuj AAM, Haque ZF, Rahman MT, Kafi MA, Saha S. 2020. Detection of antibiotic-resistant bacteria and their resistance genes from houseflies, Veterinary World, 13(2): 266-274.

4. Asaeedi SA, Ghada A, Abou El-E, Osman GH. 2017. Overexpression and Cytocidal Activity of Parasporin-1 from Bacillus thuringiensis against Human Cancer Cell Lines. Journal of Microbial \& Biochemical Technology9(5): 220-226.

5. Bahareth $\mathrm{O}$, Alsahhaf $Z$, Abdulmajeed $S$, Hijji A, Osman G. 2018. The Effect of Bacillus thuringiensis Israelensis (Bti) as a Microbial Control agent against Musca domestica in Makkah Region. Journal of 
Pure and Applied Microbiology 12(4): 2077 2085. http://dx.doi.org/10.22207/JPAM.12.4.44.

6. Bahrndorff $S$, de Jonge N, Skovgård H, Nielsen JL. 2017. Bacterial Communities Associated with Houseflies (Musca domestica L.) Sampled within and between Farms. PLOS ONE 12(1): 115.https://doi.org/10.1371/journal.pone.0169753.

7. Becker N.1997. Microbial control of mosquitoes: management of the Upper Rhine mosquito population as a model program. Parasitol.Today13: 485-487.

8. Becker N, Margalit J. 1993. Use of Bacillus thuringiensis israelensis against mosquitoes and blackflies, pp. 255-266. In: Entwistle PF, Cory JS, Bailey MJ, Higgs S. (Eds.). Bacillus thuringiensis, An Environmental Biopesticide: Theory and Practice. Wiley, New York.

9. Bellingham J, Anderson M. 1993. Variations and sexual differences in the spectral sensitivity of the compound eye of the housefly Musca domestica (L.) and the lesser housefly Fanniacanicularis(L.). Proceedings of the International Conference on Insect Pests in the Urban Environment 1: 480.

10. Boucias DG, Pendland JC. 1991. Attachment of mycopathogens to cuticle, pp. 101-128. In: Cole GT, Hoch HC. (Eds.). The Fungal Spore and Disease Initiation in Plants and Animals. Plenum Press, New York, London.

11. Boulesteix G, Le Dantec $P$, Chevalier B, Dieng M, Niang B, Diatta B. 2005. Role of Musca domestica in the transmission of multiresistant bacteria in the centers of intensive care setting in sub-Saharan Africa. Annales Françaises d'Anesthésie et de Réanimation 24: 361- 365.

12. Bravo A, Gill SS, Soberon M. 2007. Mode of action of Bacillus thuringiensis Cry and Cyt toxins and their potential for insect control. Toxicon, 49(4):423-435. doi: 10.1016/j.toxicon.

13. Carlberg G. 1986. Bacillus thuringiensis and microbial control of flies. Journal of Applied Microbiology and Biotechnology 2: 267-274.

14. Carramaschi IN, Pereira LA, Queiroz MMC, Zahner V. 2015. Preliminary screening of the larvicidal effect of Brevibacilluslaterosporus strains against the blowfly Chrysomyamegacephala (Fabricius, 1794) (Diptera: Calliphoridae). Revista da Sociedade Brasileira de Medicina Tropical, 48 (4), 427-431. DOI: 10.1590/0037-8682-0092-2015.

15. Charnley AK. 1989. Mechanisms of fungal pathogenesis in insects, pp. 85-125. In: Whipps JM, Lumsden RD. (Eds.). The Biotechnology of Fungi for Improving Plant Growth. Cambridge University, London.

16. Ciche TA, Darby C, Ehlers RU, Forst S, GoodrichBlair H. 2006. Dangerous liaisons: The symbiosis of entomopathogenic nematodes and bacteria.
Biological Control, 38(1): 22-46. https://doi.org/ 10.1016/j.biocontrol.2005.11.016

17. Crespo DC, Lecuona RE, Hogsette JA. 1998. Biological control: An important component in integrated management of Musca domestica (Diptera: Muscidae) in caged-layer poultry houses in Buenos Aires. Biological Control, 13: 16-24.

18. Cui L, Gaugler R, Wang, Y. 1993. Penetration of Steinernematid nematodes into Japanese beetle larvae, Popillia japonica (Coleoptera: Scarabaeidae). Journal of Invertebrate Pathology, 62: 73-78.

19. Davari B, Kalantar E, Zahirnia A, Moosa-Kazemi SH. 2010. Frequency of Resistance and Susceptible Bacteria Isolated from Houseflies. Iranian Journal of Arthropod-Borne Diseases 4(2):50-5.

20. Erb A, Sturmer T, Marre R, Brenner H. 2007. Prevalence of antibiotic resistance in Escherichia coli: overview of geographical, temporal, and methodological variations. European journal of clinical microbiology \& infectious diseases, 26(2): 83-90. https://doi.org/10.1007/s10096-006-0248-2.

21. Ericsson JD, Kabaluk JT, Goettel MS, Myers JH. 2007. Spinosad interacts synergistically with the insect pathogen Metarhizium anisopliae against the exitic wireworm Agriotes lineatus and Agriotes obscurus (Coleoptera: Elatridae). Journal of economic entomology, 100(1): 31-38. https://doi. org/10.1603/0022-0493(2007)100[31:siswti]2.0.co;2

22. Estruch JJ, Warren GW, Mullins MA, Nye GJ, Craig JA, Koziel MG. 1996. Vip3A, a novel Bacillus thuringiensis vegetative insecticidal protein with a wide spectrum of activities against lepidopteran insects. Proceedings of the National Academy of Sciences of the United States of America 93(11): 5389-5394. https://doi.org/10.1073/pnas.93.11.5389

23. Ezeonu FC, Chidune Gl,Idedi SC. 2001. Insecticidal properties of volatile extracts of orange peels. Bioresource Technology, 76: 273-274.

24. Farkas R, Hogsette JA,Boerzsoenyi L. 1998. Development of Hydrotaeaaenescens and Musca domestica (Diptera: Muscidae) in poultry and pig manures of different moisture content. Environmental Entomology 27: 695-699.

25. Feldhaar H. 2011. Bacterial symbionts as mediators of ecologically important traits of insect hosts. Ecological Entomology, 36: 533-543.

26. Feng MG, Proprawski TJ, Khachatourians GC. 1994. Production, formulation and application of the entomopathogenic fungus Beauveria bassianafor insect control: current status. Biocontrol Science Technolology, 4(1): 3-34. doi.org/10.1080/09583159409355309

27. Fisher ML, Fowler FE, Denning SS, Watson DW. 2017. Survival of the House Fly (Diptera: Muscidae) on Truvia and Other Sweeteners. Journal of medical entomology, 54(4): 999-1005. https://doi.org/10. 1093/jme/tjw241 
28. Fleming $\mathrm{A}$, Kumar $\mathrm{HV}$, Joyner $\mathrm{C}$, Reynolds $\mathrm{A}$, Nayduch D. 2014. Temporospatial fate of bacteria and immune effector expression in house flies (Musca domestica L.) fed GFP-E. coli O157:H7. Medical and veterinary entomology, 28(4): 364-371. doi.org/10.1111/mve.12056

29. Fotedar R, Banerjee U, Samantray JC, Shriniwas. 1992. Vector potential of hospital houseflies with special reference to Klebsiella species. Epidemiology and infection, 109(1):143-7.

30. Fotedar R, Banerjee U, Singh S, Shriniwas, Verma AK. 1992. The housefly (Musca domestica) as a carrier of pathogenic micro-organisms in a hospital environment. The Journal of hospital infection, 20(3): 209-15.

31. Fotedar R. 2001. Vector potential of houseflies (Musca domestica) in the transmission of Vibrio cholerae in India. Acta tropica, 78(1): 31-34. doi.org/10.1016/s0001-706x(00)00162-5.

32. Gaugler R. 1988. Ecological considerations in the biological control of soil-inhabiting insect pests with entomopathogenic nematodes. Agriculture, Ecosystems \& Environment, 24: 351-360. https://doi. org/10.1016/0167-8809(88)90078-3

33. Geden C J. 1990. The role of coleopteran and acarine predators in house fly population regulation in poultry production facilities, pp.177-200. In: Rutz, DA, Patterson RS. (eds.). Biocontrol of Arthropods Affecting Livestock and Poultry. Westview Press, Boulder.

34. Geden CJ, Hogsette JA. 2006. Suppression of house flies (Diptera: Muscidae) in Florida poultry houses by sustained releases of Muscidifurax raptorellus and Spalangia cameroni (Hymenoptera: Pteromalidae). Environmental Entomology,35(1): 7582. doi.org/10.1603/0046-225X-35.1.75

35. Geden CJ, Steinkraus DC, Rutz DA. 1993. Evaluation of two methods for release of Entomophtora muscae (Entomophtorales: Entomophtoraceae) to infect house flies (Diptera: Muscidae) on dairy farms. Environmental Entomology, 20: 1201-1208.

36. GedenCJ. 2012. Status of biopesticides for control of house flies. Journal of Biopesticides 5 (Supplementary): 1-11.

37. Graczyk TK, Knight R, Gilman RH, Cranfield MR. 2001. The role of nonbiting flies in the epidemiology of human infectious diseases. Microbes and Infection, 3(3):231-235.

38. Graham JP, Price LB, Evans SL, Graczyk TK, Silbergeld EK. 2009. Antibiotic resistant enterococci and staphylococci isolated from flies collected near confined poultry feeding operations. The Science of the total environment, 407(8):2701-2710. doi.org/ 10.1016/j.scitotenv.2008.11.056

39. Greene GL, Guo Y, Chen H. 1998. Parasitization of house fly pupae (Diptera: Muscidae) by
Spalangianigroaenea (Hymenoptera: Pteromalidae) in cattle feedlot environments. Biological Control, 12: 7-13.

40. Grewal P, Georgis R. 1999. Entomopathogenic nematodes,pp. 271-299. In: Hall FR, MennJJ (Eds.). Biopesticides Use and Delivery. Humana Press, Inc., Totowa, NJ.

41. Hayes JR, English L, Carr LE, Wagner DD, Joseph SW. 2004. Multiple-antibiotic resistance of Enterococcus spp. Isolated from commercial poultry production environments. Applied and Environmental Microbiology, 70(10): 6005-6011. doi.org/10.1128/AEM.70.10.6005-6011.2004

42. Hemmatinezhad B, Ommi D, Hafshejani TT, Khamesipour F. 2015. Molecular detection and antimicrobial resistance of Pseudomonas aeruginosa from houseflies (Musca domestica) in Iran. Journal of Venomous Animals and Toxins including Tropical Diseases, 21:18. https://doi.org/ 10.1186/s40409-015-0021-z

43. Hill IR. 1985. Effects on non-target organisms in terrestrial and aquatic environments, pp 151-262.In: Leahey JP (eds.). The pyrethroid insecticides, Taylor and Francis, Philadelphia,

44. Himathongkham S, Bahari S, Riemann H, Cliver D. 1999. Survival of Escherichia coli O157:H7 and Salmonella typhimurium in cow manure and cow manure slurry. FEMS Microbiology Letter,s 178: 251-257.

45. Howard J, Wall R. 1996b. Autosterilization of the housefly, Musca domestica, using the chitin synthesis inhibitor triflumuron on sugar-baited targets. Medical \& Veterinary Entomology, 10: 97-100.

46. Howard J, Wall R. 1996c. Autosterilization of the house fly, Musca domestica (Diptera: Muscidae) in poultry houses in north-east India. Bulletin Entomological Research, 86: 363-367.

47. Hulten K, Han SW, Enroth H, Klein PD, Opekun AR, Gilman RH, Evans DG, Engstrand L, Graham DY, ElZaatari FAK. 1996. Helicobacter pylori in the drinking water in Peru. Gastroenterology, 110: 1031-1035. https://doi.org/10.1053/gast.1996.v110.pm8612990

48. Indrasith LS, Suzuki N, Ogiwara K, Asano S, Hori H. 1992. Activated insecticidal crystal proteins from Bacillus thuringiensis serovars killed adult house flies. Letters in Applied Microbiology, 14(4): 174-177. https://doi.org/10.1111/j.1472-765X.1992.tb00677.x

49. Isman MB. 2000. Plant essential oils for pest and disease management. Crop Protection, 19: 603-608.

50. Joyner C, Mills MK, Nayduch D. 2013. Pseudomonas aeruginosa in Musca domestica L.: temporospatial examination of bacteria population dynamics and house fly antimicrobial responses. PLOS ONE, 8(11):1-9.

51. Kaufman PE, Rutz DA, Waldron JK. 2002. Seasonal variation in Carcinopspumilio (Coleoptera: 
Histeridae) dispersal and potential for suppression of dispersal behavior. Journal of Medical Entomology, 39: 106-111.

52. Kaya H, Gaugler R. 1993. Entomopathogenic nematodes. Annual Review of Entomology 38(1): 181- 206.

53. Keiding J. 1986. The house fly: biology and control. WHO Vector Control Series 63.

54. Kellar B, Langenfruch GA. 1993. Control of coleopteran pests by Bacillus thuringiensis, pp 171191. In: Entwistle PF, CoryJS, Bailey MJ, Higgs, S. (Eds.).Bacillus thuringiensis, anEnvironmental Biopesticide. Theory and Practice, Wiley, New York.

55. Kelling FJ. 2001. Olfaction in houseflies: Morphology and electrophysiology [Groningen]: University of Groningen, 144pp.

56. Kelly SM, Pitcher MCL, Farmery SM, Gibson GR. 1994. Isolation of Helicobacter pylori from feces of patients with dyspepsia in the United Kingdom. Gastroenterology, 107: 167-1674.

57. Khachatourians GG. 1991. Physiology and genetics of entomopathogenic fungi, pp. 613-663. In: Arora DK, AjelloL, MulkerjikG. (Eds.). Handbook of Applied Mycology. Marcel Dekker, New York,.

58. Khamesipour F, Lankarani KB, Honarvar B, Kwenti TE. 2018. A systematic review of human pathogens carried by the housefly (Musca domestica L.). BMC Public Health, 18: 1049.

59. King BH. 1997. Effects of age and burial of house fly pupae (Diptera: Muscidae) on parasitism by Spalangiacameroni and Muscidifurax raptor (Hymenoptera: Pteromalidae). Environmental Entomology, 26: 410-415. https://doi.org/10.1093/ ee/26.2.410

60. Kobayashi M, Sasaki T, Saito N, Tamura k, Suzuki K, Watanabe H, Agui N. 1999. Houseflies: not simple mechanical vectors of enterohemorrhagic Escherichia coli 0157:H7. American Journal of Tropical Medicine and Hygiene, 61: 625-629.

61. Kongsuwan K, Gough J, Kemp D, McDevitt A, Akhurst R. 2005. Characterization of a new Bacillus thuringiensis endotoxin, Cry47Aa, from strains that are toxic to the Australian sheep blowfly, Luciliacuprina. FEMS Microbiology Letters, 252(1):127-136. https://doi.org/10.1016/j.femsle. 2005.08.037

62. Koul O, Walia S, Dhaliwal GS. 2008. Essential oils as green pesticides: Potential and constraints. Biopesticides Internationa, I 4: 63-84.

63. Kozaki T, Brady SG, Scott JG. 2009. Frequencies and evolution of organophosphate insensitive acetylcholinesterase alleles in laboratory and field populations of the house fly, Musca domestica L. Pesticide Biochemistry and Physiology, 95: 6-11.

64. Kumar P, Mishra S, Malik A Satya S. 2011. Repellent, larvicidal and pupicidal properties of essential oils and their formulations against the housefly, Musca domestica. Medical and Veterinary Entomology, 25: 302-310.

65. Kuramoto H, Shimazu M. 1997. Control of House Fly Populations by Entomophthora muscae (Zygomycotina: Entomophthorales) in a Poultry House. Applied Entomology and Zoology, 32(2): 325-331.

66. Labib IM, Rady M. 2001. Application of Bacillus thuringiensis in poultry houses as a biological controlagent against the housefly, Musca domestica sorbens. Journal of the Egyptian Society of Parasitology, 31: 531-544.

67. Lecuona RE, Turica M, Tarocco F, Crespo DC. 2005. Microbial control of Musca domestica (Diptera: Muscidae) with selected strains of Beauveria bassiana. Journal of Medical Entomology, 42(3): 332-336.

68. Levy S, Marshall B. 2004. Antibacterial resistance worldwide: causes, challenges, and responses. Nature Medicin, 10: 122-9.

69. Lietze VU, Abd-Alla AMM, Vreysen MJB, Geden CG, Boucias DG. 2011. Salivary gland hypertrophy viruses: a novel group of insect pathogenic viruses. Annual Review of Entomology, 56: 63-80.

70. Lietze VU, Geden CJ, Blackburn P, Boucias DG. 2007. Effects of salivary gland hypertrophy virus on the reproductive behavior of the housefly, Musca domestica. Applied and Environmental Microbiology, 73: 6811-6818.

71. Lietze VU, Salem TZ, Prompiboon P, Boucias DG. 2010. Tissue tropism of the Musca domestica salivary gland hypertrophy virus. Virus Research, 155: 20-27.

72. Lietze VU, Sims KR, Salem TZ, Geden CJ, Boucias DG. 2009. Transmission of MdSGHV among adult house flies, Musca domestica (Diptera: Muscidae), occurs via salivary secretions and excreta. Journal of Invertebrate Pathology, 101: 49-55.

73. Lindquist DA, Abusowa M, Hall MJR. 1992. The New World screwworm fly in Libya: a review of its introduction and eradication. Medical and veterinary entomology, 6(1): 2-8. https://doi.org/10.1111/j. 1365-2915.1992.tb00027.x

74. Lysyk TJ, Kalischuk-tymensen LD, Rochon K, Selinger LB. 2010. Activity of Bacillus thuringiensis Isolates Against Immature Horn Fly and Stable Fly (Diptera: Muscidae), Journal of Economic Entomology, 103(3): 1019-1029. http: //doi.org/10.1603/EC10018.

75. Macovei L, Zurek L. 2006. Ecology of Antibiotic Resistance Genes: Characterization of Enterococci from Houseflies Collected in Food Settings. Applied and Environmental Microbiology, 72: 4028-4035.

76. Malik A, Singh N, Satya S. 2007. House fly (Musca domestica): a review of control strategies for a challenging pest. Journal of Environmental Science and Health, Part B, 42: 453-469. 
77. Martens EC, Vivas El, Heungens K, Cowles CE, Goodrich-Blair H. 2004. Investigating mutualism between entomopathogenic bacteria and nematodes. Nematology Monographs and Perspectives (2). Proceedings of the Fourth International Congress of Nematology, 2: 447-462.

78. Meerburg BG, Vermeer HM, Kijlstra A. 2007. Controlling risks of pathogen transmission by flies on organic pig farms: a review. Outlook on Agriculture, 36: 193-197.

79. Memmi BK. 2010. Mortality and knockdown effects of imidacloprid and methomyl in house fly (Musca domestica L., Diptera: Muscidae) populations. Journal of Vector Ecology, 35: 144-148.

80. Mian LS, Maag H, Tacal JV. 2002. Isolation of Salmonella from muscoid flies at commercial animal establishments in San Bernardino County, California. Journal of Vector Ecology, 27: 82-85.

81. Miller JA, Chamberlain WF. 1989. Azadirachtin as a larvicide against the horn fly, stable fly, and house fly. Journal of Economic Entomology, 82: 1375-1378.

82. Miller RW, Pickens LG, Gordon CH. 1971. Effect of Bacillus thuringiensis in cattle manure on house fly (Diptera: Muscidae) larvae. Journal of Economic Entomology, 64: 902-903.

83. Mullens BA, Meyer JA, Cyr TL. 1987. Infectivity of insect-parasitic nematodes (Rhabditida: Steinernematidae, Heterorhabditidae) for larvae of some manure-breeding flies (Diptera: Muscidae). Environmental Entomology, 16: 769-773.

84. Mwamburi LA. 2008. Biological control of the common housefly (Musca domestica L.) using Bacillus thuringiensis (ishiwata) berliner var. israelensisand Beauveriabassiana(bals.) vuillemin in caged poultry facilities. Thesis (Ph.D.)-University of KwaZulu-Natal, Pietermaritzburg.214pp.

85. Nandi S, Maurer JJ, Hofacre C, Summers AO. 2004. Gram-positive bacteria are a major reservoir of Class 1 antibiotic resistance integrons in poultry litter. Proceedings of the National Academy of Sciences of the United States of America, 101(18): 7118-7122. https://doi.org/10.1073/pnas.0306466101

86. Nayduch D, Pittman Noblet G, Stutzenberger FJ. 2002. Vector potential of houseflies for the bacterium Aeromonas caviae. Medical and Veterinary Entomology, 16: 193-198.

87. Nazari M, Mehrabi T, Hosseini SM, Alikhani MY. 2017. Bacterial Contamination of Adult House Flies (Musca domestica) and Sensitivity of these Bacteria to Various Antibiotics, Captured from Hamadan City, Iran. Journal of clinical and diagnostic research: JCDR 11(4): DC04-DC07. https://doi.org/10.7860/ JCDR/2017/23939.9720.

88. Nazni WA, Seleena B, Lee HL, Jeffery JT, Rogayah TAR, Sofian MA. 2005. Bacteria fauna from the house fly, Musca domestica (L.). Tropical Biomedicine, 22(2): 225-231.

89. Nichols GL. 2005. Fly transmission of campylobacter. Emerging infectious disease, 3: 361364.

90. Noorman N. 2001. Pheromones of the housefly, University of Groningen, University Medical Center Groningen.125pp.

91. Oberlander H, Silhacek DL, Shaaya E, Ishaaya I. 1997. Current status and future perspectives of the use of insect growth regulators for the control of stored product insects. Journal of Stored Products Research, 33: 1-6.

92. Oi M, Dauterman W, Motoyama N. 1992. Toxicokinetic analysis of dermally applied diazinon in resistant and susceptible house flies, Musca domestica L. Applied Entomology and Zoology, 27: 371-383.

93. Olsen AR, Hammack TS. 2000. Isolation of Salmonella spp. from the housefly, Muscadomestica L., and the dump fly, Hydrotaeaaenescens (Wiedemann) (Diptera: Muscidae), at caged-layer houses. Journal of FoodProtection, 63: 958-960.

94. Palacios SA, Bertoni A, Rossi Y, Santander R, Urzua A. 2009a. Efficacy of essential oils from native medicinal plants of central Argentina against the house fly, Muscadomestica L. Molecules, 14: 19381947.

95. Palacios SA, Bertoni A, Rossi Y, Santander R, Urzua A. 2009b. Efficacy of essential oils from edible plants as insecticides against the house fly, Musca domestica L. Molecules, 14: 1938-1947.

96. Pap L, Farkas R. 1994. Monitoring of resistance of insecticides in house fly (Musca domestica) populations in Hungary. Pesticide Science, 40: 245258.

97. Park R, Dzialo MC, Spaepen S, Nsabimana D, Gielens K, Devriese H, Crauwels S, Tito RY, Raes J, Lievens B,Verstrepen KJ. (2019). Microbial communities of the house fly Musca domestica vary with geographical location and habitat. Microbiome, 7: 147. http://doi.org/10.1186/s40168019-0748-9

98. Pavela R. 2008. Insecticidal properties of several essential oils on the house fly (Musca domestica L.). PhytotherapyResearch, 22: 274-278.

99. Pawson BM, Petersen JJ. 1988. Dispersal of Muscidifuraxzaraptor(Hymenoptera: Pteromalidae), a filth fly parasitoid, at dairies in eastern Nebraska. Environmental Entomology, 17(2): 398-402. https://doi.org/10.1093/ee/17.2.398

100. Pessanha RR, Carramaschi IN, Dos Santos, Mallet JR, Queiroz MM, Zahner V. 2015. Evaluation of larvicidal activity and effects on post embrionary development of laboratory reared Luciliacuprina (Wiedemann, 1830) (Diptera: Calliphoridae), treated 
with Brevibacillus laterosporus. Journal of Invertebrate Pathology, 128: 44-46.

101. Peters A, Ehlers R-U. 1994. Susceptibility of leatherjackets (Tipulapaludosaand Tipula oleracea; Tipulidae; Nematocera) to the entomopathogenic nematode Steinernemafeltiae. Journal of Invertebrate Pathology, 63: 163-171. https://doi.org/10.1006/ jipa.1994.1031

102. Pimental D, Perkins JH. 1980. Pest control: Cultural and environmental aspects. AAAS selected symposium, 43, Westview Press, Colorado. 243 pp.

103. Pinnock DE. 1994. The use of Bacillus thuringiensis for control of pests of livestock. Agriculture Ecosystems \& Environment, 49: 59-63. doi.org/ 10.1016/0167-8809(94)90023-X

104. Rady MH, Abdel Raouf N, Labib I, Merdan Al. 1992. Bacterial contamination of the housefly Musca domestica, collected from 4 hospitals at Cairo. Journal of the Egyptian Society of Parasitology, 22: 279-288.

105. Renn N. 1998. The efficacy of entomopathogenic nematodes for controlling housefly infestations of intensive pig units. Medical and veterinary entomology, 12(1): 46-51. https://doi.org/10.1046/j. 1365-2915.1998.00081.x

106. Rodrigues IB, Tadei WP, Dias JMCS. 1988. Studies on the Bacillus sphaericus larvicidal activity against malaria vector species in Amazonia. Memórias do Instituto Oswaldo Cruz, 93(4): 441- 444. https://doi.org/10.1590/S0074-02761998000400005

107. Rosef O, Kapperud G. 1983. House flies (Musca domestica) as possible vectors of Campylobacter fetus subsp. jejuni. Applied and Environmental Microbiology, 45(2): 381-383.

108. Ruiu L, Delrio G, Ellar DJ, Floris I, Paglietti B, Rubino S, Satta A. 2006. Lethal and sub-lethal effects of Brevibacilluslaterosporus on the housefly (Musca domestica). Entomologia Experimentalis Applicata, 118(2):137-144. https://doi.org/10.1111/j.1570-7458. 2006.00370.x

109. Ruiu L, Satta A, Floris I. 2008. Immature house fly (Musca domestica) control in breeding sites with a new Brevibacillus laterosporus formulation. Environmental Entomology, 37: 505-509.

110. Ruiu L, Satta A, Floris I. 2011. Comparative applications of azadirachtin and Brevibacillus laterosporus based formulations for house fly management experiments in dairy farms. Journal of Medical Entomology 48(2): 345-350. https://doi.org /10.1603/ME09299

111. Rupes V, Ryba J, Hanzlova H, Weiser J. 1987. The efficiency of beta-exotoxin of Bacillus thuringiensis on susceptible and resistant house fly, pp262265.In: Proceedings of the International Conference of Medical and Veterinary Dipterology, (Olejnicek, J., eds.), Ceske, Budejovice.
112. Saccà G. 1964. Comparative bionomics in the genus Musca. Annual Review of Entomology, 9: 341358.

113. Samish M, Glazer I. 1992. Infectivity of entomopathogenic nematodes (Steinernematidae and Heterorhabditidae) to female ticks of Boophilusannulatus(Arachnida: Ixodidae). Journal of Medical Entomology,29: 614-618.

114. Sanchez-Arroyo H, Capinera JL. 2014. House fly, Musca domestica Linnaeus Insecta: Diptera: Muscidae). Institute Food Agricultural Sciences, 47:1-7.

115. Sarwar M, 2016.Life History of House Fly Musca domestica Linnaeus (Diptera: Muscidae), its Involvement.International Journal For Research In Applied And Natural Science.2(7): 31-42.

116. Sasaki T, Kobayashi M, Agui N. 2000. Epidemiological potential of excretion and regurgitation by Musca domestica (Diptera: Muscidae) in the dissemination of Escherichia coli 0157: H7 to food. Journal of Medical Entomology, 37: 945-949. https://doi.org/10.1603/0022-258537.6.945

117. Schnepf E, Crickmore N, Van Rie J, Lereclus D, Baum J, Feitelson J, Ziegler DR, Dean DH. 1998. Bacillus thuringiensis and its pesticidal crystal proteins. Microbiology and Molecular Biology Reviews, 62: 775-806. http://doi.org/10.1128/MMBR. 62.3.775-806.1998

118. Scott JG, Geden CJ, Rutz DA, Liu N. 1991. Comparative toxicity of seven insecticides to immature stages of Musca domestica (Diptera: Muscidae) and two of its important biological control agents: Muscidifurax raptor and Spalangia cameroni(Hymenoptera: Pteromalidae). Journal of Economic Entomology, 84: 776-779.

119. Scott JG, Liu N, Kristensen M, Clark AG. 2009. A case for sequencing the genome of Musca domestica (Diptera: Muscidae). Journal of medical entomology, 46(2): 175-182. https://doi.org/10.1603/ 033.046 .0202

120. Service MW, 2000. Medical entomology for students'. Second edition. Cambridge University Press, $2000 \mathrm{pp}$.

121. Shah RM, Shad SA, Abbas N. 2015. Mechanism, stability and fitness cost of resistance to pyriproxyfen in the house fly, Musca domestica L. (Diptera: Muscidae). Pesticide Biochemistry and Physiology, 119: 67-73.

122. Sharma RN, Saxena KN. 1974. Orientation and developmental inhibition in the housefly by certain terpenoids. Journal of Medical Entomology, 11: 617- 621.

123. Shen J, Plapp JrFW. 1990. Cyromazine resistance in the house fly (Diptera: Muscidae): Genetics and cross resistance to diflubenzuron. Journal of Economic Entomology, 83: 1689-1697. 
124. Skovgård H, Jespersen JB. 1999. Activity and relative abundance of hymenopterous parasitoids that attack puparia of Musca domestica and Stomoxys calcitrans (Diptera: Muscidae) on confined pig and cattle farms in Denmark. Bulletin of Entomological Research, 89: 263-269.

125. Smallegange RC. 2004. Control of the housefly (Musca domestica). Entomologische Berichten, 64(3): 87-92

126. Solà-Ginés M, González-López JJ, Cameron-Veas $K$, Piedra-Carrasco N, Cerdà- Cuéllar M, MiguraGarcia L. 2015. Houseflies (Musca domestica) as Vectors for Extended-Spectrum $\beta$-LactamaseProducing Escherichia coli on Spanish Broiler Farms. Applied and Environmental Microbiology, 81(11): 3604-11.

127. Songe MM, Hang'ombe BM, TJD KJ, Grace D. 2017. Antimicrobial Resistant Enteropathogenic Escherichia coli and Salmonella spp. in Houseflies Infesting Fish in Food Markets in Zambia. International Journal of Environmental Research and Public Health, 14(1): 21.

128. Steinkraus DC, Geden CJ, Rutz DA. 1993. Prevalence of Entomophthora muscae (Cohn) Fresenius (Zygomycetes: Entomophthoraceae) in houseflies (Diptera: Muscidae) on dairy farms in New York and induction of epizootics. Journal of Biological Control, 3: 93-100.

129. Sukontason K, Bunchoo M, Khantawa B, Sukontaso n K, Piangjai S, Choochote W. 2000. Musca domestica as a Mechanical Carrier of Bacteria in Chiang Mai, North Thailand. Journal of Vector Ecology, 25: 114-117.

130. Sulaiman S, Othman MZ, Aziz AH. 2000. Isolations of enteric pathogens from synanthropic flies trapped in downtown Kuala Lumpur. Journal of Vector Ecology, 25: 90-93.

131. Szalanski AL, Owens CB, Mckay T, Steelman CD. 2004. Detection of Campylobacter and Escherichia coli O157:H7 from filth flies by polymerase chain reaction. Medical and Veterinary Entomology, 18(3): 241-246.

132. Tajbakhsh E, Tajbakhsh S, Khamesipour F. 2015. Isolation and Molecular Detection of Gram Negative Bacteria Causing Urinary Tract Infection in Patients Referred to Shahrekord Hospitals, Iran. Iranian Red Crescent Medical Journal, 17(5): doi.org/10.5812 /ircmj.17(5)2015.24779.

133. Tan SW, Yap KL, Lee HL. 1997. Mechanical transport of rotavirus by the legs and wings of Musca domestica (Diptera: Muscidae). Journal of Medical Entomology, 34(5):527 - 531.

134. Taylor DB, Moon R, Gibson G, Szalanski A. 2006. Genetic and Morphological Comparisons of New and Old World Populations of Spalangia Species (Hymenoptera: Pteromalidae), Annals of the Entomological Society of America, 99(5): 799-
808. doi.org/10.1603/0013-8746(2006)99[799:GAM CON]2.0.CO;2

135. Taylor DB, Moon RD, Mark DR. 2012. Economic impact of stable flies (Diptera: Muscidae) on dairy and beef cattle production. Journal of Medical Entomology, 49: 198-209.

136. Taylor DB, Szalanski AL, Adams BJ, Peterson II RD. 1998. Susceptibility of house fly (Diptera: Muscidae) larvae to entomopathogenic nematodes (Rhabditida: Heterorhabditidae, Steinernematidae). Environmental Entomology, 27(6): 1514-1519.

137. Teakle RE. 1994. Present use of, and problems with, Bacillus thuringiensis in Australia. Agriculture, Ecosystems \& Environment, 49: 39-44.

138. Thomas JE, Gibson GR, Darboe MK, Dale A, Weaver LT. 1992. Isolation of Helicobacter pylori from human feaces. The Lancet, 340: 1194 - 1195.

139. Tsankova RN, Luvchiev VI. 1993. Laboratory investigations on the larval zoophagy of Ophyra capensis: an antagonist of Musca domestica. Applied Parasitology, 34: 221-228.

140. Tsao R, Lee S, Rice PJ, Jensen C, Coats JR. 1995. Monoterpenoids and Their Synthetic Derivatives as Leads for New Insect-Control Agents. Synthesis and Chemistry of Agrochemicals N, 584(28); 312324. http://doi.org/10.1021/bk-1995-0584.ch028.

American Chemical Society.

141. Urban JE, Broce A. 2000. Killing of flies in electrocuting insect traps releases bacteria and viruses. Current Microbiology, 41, 267-270.

142. Urzua A, Santander R, Echeverria J, Cabezas C, Palacios SM, Rossi Y. 2010. Insecticide properties of the essential oils from Haplopappus foliosus and Bahiaambrosoides against the housefly, Musca domestica L. Journal of the Chilean Chemistry Society, 55: 392-395.

143. Van Emden, HF, Peakall DB. 1996. Beyond Silent Spring: Integrated Pest Management and Chemical Safety. Springer 320pp.

144. Vilcinskas A. 2010. Coevolution between pathogenderived proteinases and proteinase inhibitors of host insects. Virulence, 1:206-214.

145. Watson DW, Petersen JJ. 1993. Seasonal activity of Entomophthora muscae (Zygomycetes: Entomophthorales) in Musca domestica L. (Diptera: Muscidae) with reference to temperature and relative humidity. Biological Control, 3: 182-190.

146. Weeks EN, Machtinger ET, Gezan SA, Kaufman PE, Geden C J. 2017. Effects of four commercial fungal formulations on mortality and sporulation in house flies (Musca domestica) and stable flies (Stomoxys calcitrans). Medical and veterinary entomology, 31(1): 15-22. https://doi.org/10.1111/mve.12201

147. Willikins RM, Metcalfe RJ. 1993. Toxicity of soil applied herbicides to brine shrimp larvae (Artemia salina) and synergism with other pesticides. 
Proceeding Righton Grop. protect confidentiality, 7: 163-168.

148. Winpisinger KA, Ferketich AK, Berry RL, Moeschberger ML. 2005. Spread of Musca domestica (Diptera: Muscidae), from two caged layer facilities to neighboring residences in rural Ohio. Journal of Medical Entomology, 42:732-8.

149. World Health Organization 2004.Trachoma. (http://www. who.int/pbd/blindness/trachoma/en/).

150. Zimmer CR, Dias de Castro LL, Pires SM, Delgado Menezes AM, Ribeiro PB, LeivasLeite FP. 2013. Efficacy of entomopathogenic bacteria for control of Musca domestica. Journal of Invertebrate Pathology, 114: 241-244.

151. Zurek L, Denning SS, Schal C, Watson DW. 2001. Vector competence of Musca domestica (Diptera: Muscidae) for Yersiniapseudotuberculosis. Journal of Medical Entomology, 38: 333-335.

152. Zurek L, Ghosh A. 2014. Insects represent a link between food animal farms and the urban environment for antibiotic resistance traits. Applied and Environmental Microbiology, 80: 3562-3567. 